\title{
New speleothem data from Molinos and Ejulve caves reveal Holocene hydrological variability in northeast Iberia
}

\author{
Ana Moreno $^{\mathrm{a} *}$, Carlos Pérez-Mejías ${ }^{\mathrm{a}, \mathrm{b}}$, Miguel Bartolomé ${ }^{\mathrm{a}, \mathrm{b}}$, Carlos Sancho $^{\mathrm{b}}$, Isabel Cacho $^{\mathrm{c}}$, Heather Stoll ${ }^{\mathrm{d}, \mathrm{e}}$, \\ Antonio Delgado-Huertas ${ }^{\mathrm{f}}$, John Hellstrom ${ }^{\mathrm{g}}$, R. Lawrence Edwards ${ }^{\mathrm{h}}$, Hai Cheng ${ }^{\mathrm{h}, \mathrm{i}, \mathrm{j}}$ \\ ${ }^{a}$ Department of Geoenvironmental Processes and Global Change, Pyrenean Institute of Ecology - CSIC, Avenida Montañana 1005 50059, Zaragoza, Spain \\ ${ }^{\mathrm{b}}$ Earth Sciences Department, University of Zaragoza, C/Pedro Cerbuna 12 50009, Zaragoza, Spain \\ ${ }^{\mathrm{c} C R G}$ Marine Geosciences, Department of Stratigraphy, Paleontology and Marine Geosciences, Faculty of Geology, University of Barcelona, C/Martí i \\ Franqués, s/nº 08028, Barcelona, Spain \\ ${ }^{\mathrm{d}}$ Department of Geology, University of Oviedo, C/Arias de Velasco, $\mathrm{s} / \mathrm{n}^{\circ} 33005$ Oviedo, Spain \\ ${ }^{\mathrm{e}}$ Geological Institute, NO G59, Department of Earth Sciences, Sonneggstrasse 5, ETH 8092, Zurich, Switzerland \\ ${ }^{\mathrm{f}}$ Stable Isotope Biogeochemistry Laboratory, IACT-CSIC, Avda. de Las Palmeras n ${ }^{\circ} 4$ 18100, Armilla, Granada, Spain \\ ${ }^{\mathrm{g}}$ School of Earth Sciences, The University of Melbourne, VIC 3010, Australia

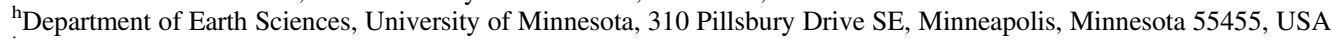 \\ iState Key Laboratory of Loess and Quaternary Geology, Institute of Earth Environment, Chinese Academy of Sciences, Xian 710075, China \\ ${ }^{\mathrm{j}}$ Institute of Global Environmental Change, Xian Jiaotong University, Xian 710049, China
}

(ReCEIVED November 8, 2016; AcCEPTED April 4, 2017)

\begin{abstract}
New speleothem records from northeastern Iberian caves provide data to explore the climatic patterns during the Holocene. We present $\delta^{13} \mathrm{C}$ and $\mathrm{Mg} / \mathrm{Ca}$ from three speleothems from two different caves located in the Iberian Range allowing replication of the climatic signal for several millennia. Through the integration of those stalagmites covering since the Holocene onset to $2 \mathrm{ka}$, the early Holocene $(11.7-8.5 \mathrm{ka})$ appears as the wettest interval. A marked change towards aridity is observed during the middle Holocene (8.5-4.8 ka) and an increase of humidity afterwards (4.8-2 ka). This three-part pattern, contrasting with other Iberian sequences, seems to be associated with the different role that seasonality has played in the response of different proxies (or records) to changes in water availability. Interpreting our speleothem records as changes in winter-spring precipitation along the Holocene allows reconciling previous data on hydrological variability from the western Mediterranean borderlands.
\end{abstract}

Keywords: Stable isotopes; Trace metals; Stalagmites; Winter-spring hydrology; Iberia; Holocene

\section{INTRODUCTION}

In Mediterranean regions, the Holocene has traditionally been divided based more on humidity variations than on temperature changes, with the first part of the Holocene characterized by humid conditions correlating with the North African Humid Period (Jalut et al., 2000) followed by a transition to drier conditions at about 6-4 $\mathrm{ka}$ in response to insolation decline (Roberts et al., 2011). This pattern was recently questioned by Magny et al. (2013), who showed a strong regional heterogeneity in environmental responses to climate changes in the Central Mediterranean region by considering separately records located north (e.g., Accesa, Ledro, and

*Corresponding author at: Department of Geoenvironmental Processes and Global Change, Pyrenean Institute of Ecology - CSIC, Avenida Montañana 1005, 50059 Zaragoza, Spain. E-mail address: amoreno@ipe.csic.es (A. Moreno).
Cerin lakes) versus south (e.g., Preola and Pergusa lakes) of $40^{\circ} \mathrm{N}$ latitude. This complexity, together with the different role that seasonality has played in the response of different proxies (or records) to changes in water availability (e.g., lake levels, vegetation cover, or isotopic records) have led to apparent contradictions in temperature and precipitation reconstructions that still need to be understood on a regional scale.

The northeastern Iberian Peninsula is a particularly interesting region to explore these contradictions during the Holocene, since two contrasting climatic regimes coexist: the Atlantic or Oceanic climate and the Mediterranean realm. Thus, for example, lake records from the Pyrenees progress from a dominantly Atlantic pattern in the western sector (González-Sampériz et al., 2006) to a stronger Mediterranean imprint in the central region (Pérez-Sanz et al., 2013). Coherently, in the central southern Pre-Pyrenees, lake records closely follow the typical Mediterranean Holocene succession, with a delayed onset of humid conditions 
(ca. $9.5 \mathrm{cal} \mathrm{ka} \mathrm{BP)} \mathrm{and} \mathrm{a} \mathrm{decrease} \mathrm{in} \mathrm{humidity} \mathrm{after} \mathrm{5-4.5} \mathrm{cal} \mathrm{ka}$ BP (Morellón et al., 2009), a pattern that is supported by terrestrial proxies obtained from western Mediterranean marine records (e.g., pollen in the Alboran Sea [Fletcher et al., 2013] and fluvial input in the Balearic Sea [Frigola et al., 2007]). Most of these archives are known to mainly record annual conditions or summer climate (in the case of some biological proxies). In contrast, speleothems provide the opportunity to reconstruct climate conditions during the rainfall season (Wackerbarth et al., 2010; Fohlmeister et al., 2012).

Unfortunately, studied speleothem records are scarce in the Iberian Peninsula, excluding those under the direct influence of Atlantic climate and westerly winds. Thus, Holocene speleothem records have been obtained on Northern Spain, e.g., Serra do Courel (Railsback et al., 2011) and the southern (Domínguez-Villar et al., 2008, 2009, 2017; Martín-Chivelet et al., 2011) and northern (Stoll et al., 2013; Smith et al., 2016) Cantabrian mountains. Only one Holocene published speleothem record comes from an area under the typical Mediterranean climate (Sierra de Mijas, Southern Spain), characterized today by a strongly seasonal climate, with hot-dry summers and cool-wet winters (October-April) (Walczak et al., 2015). That record, using stalagmite density as a water-excess proxy, indicates a decrease in humidity from a wet early Holocene to a dry mid-Holocene at around $5 \mathrm{ka}$. Our study presents the first climate reconstruction based on speleothems from two caves (Molinos and Ejulve) from the Iberian Range in northeastern Iberia (Fig. 1) covering the Holocene period that can be interpreted in terms of changes in water availability under a continental Mediterranean climate (Fig. 2). This work provides a conciliatory picture of Holocene water availability across Mediterranean Iberia.

\section{REGIONAL SETTING AND CAVE CHARACTERISTICS}

This study includes the analyses of three speleothems obtained from two caves located in the central sector of the Iberian Range, an alpine intraplate orogen in northeastern Iberia. Regional geological bedrock is made of Upper TriassicJurassic limestones, Lower Cretaceous detrital rocks, and Upper Cretaceous limestones and dolostones that are affected by northwest-southeast- and northeast-southwesttrending folds, thrusts, and faults (Fig. 2B). The Grutas de Cristal or Graderas Cave (Molinos, Teruel), hereafter Molinos cave $\left(40^{\circ} 47^{\prime} 33^{\prime \prime} \mathrm{N} ; 0^{\circ} 26^{\prime} 57^{\prime \prime} \mathrm{W} ; 1050 \mathrm{~m}\right.$ asl), is a small touristic cavity that developed in limestones of Cenomanian-Turonian age, whereas El Recuenco Cave

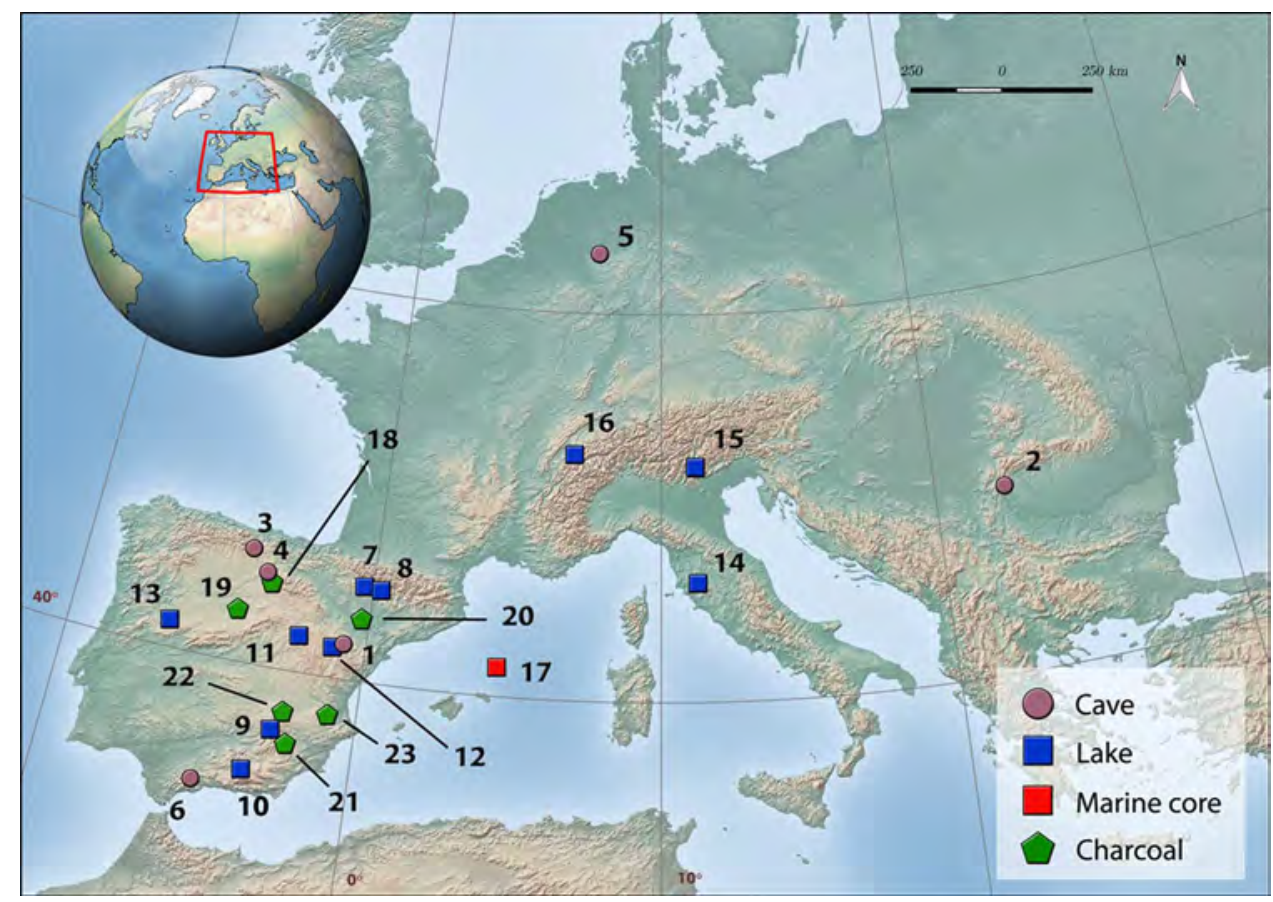

Figure 1. (A) Location of the records discussed in the text. (1) Molinos and Ejulve caves (this study). (2) Poleva Cave (Constantin et al., 2007). (3) Cobre and Kaite caves (Domínguez-Villar et al., 2008, 2009, 2017; Martín-Chivelet et al., 2011). (4) Cueva Mayor (MartínChivelet et al., 2011). (5) Bunker Cave (Fohlmeister et al., 2012). (6) El Refugio Cave (Walczak et al., 2015). (7) Estanya Lake (Morellón et al., 2008, 2009). (8) Basa de la Mora lake (Pérez-Sanz et al., 2013). (9) Siles lake (Carrión, 2002). (10) Borreguiles de la Virgen (García-Alix et al., 2012). (11) Ojos del Tremedal (Stevenson, 2000). (12) Villarquemado paleolake (Aranbarri et al., 2014). (13) El Maillo sequence (Morales-Molino et al., 2013). (14) Accesa Lake (Magny et al., 2003). (15) Ledro Lake (Magny et al., 2003). 16. Cerin lake (Magny et al., 2003). (17) MD99-2343 (Frigola et al., 2007). (18) Las Pardillas (Sánchez-Goñi and Hannon, 1999). (19) El Carrizal (Franco-Múgica et al., 2005). (20) Hoya del Castillo (Davis and Stevenson, 2008). (21) Cañada de la Cruz (Carrión et al., 2001). (22) Villaverde (Carrión et al., 2001b). (23) Navarrés (Carrión and van Geel, 1999). Blue squares include lakes, peat bogs, and paleolakes. (For interpretation of the references to color in this figure legend, the reader is referred to the web version of this article.) 


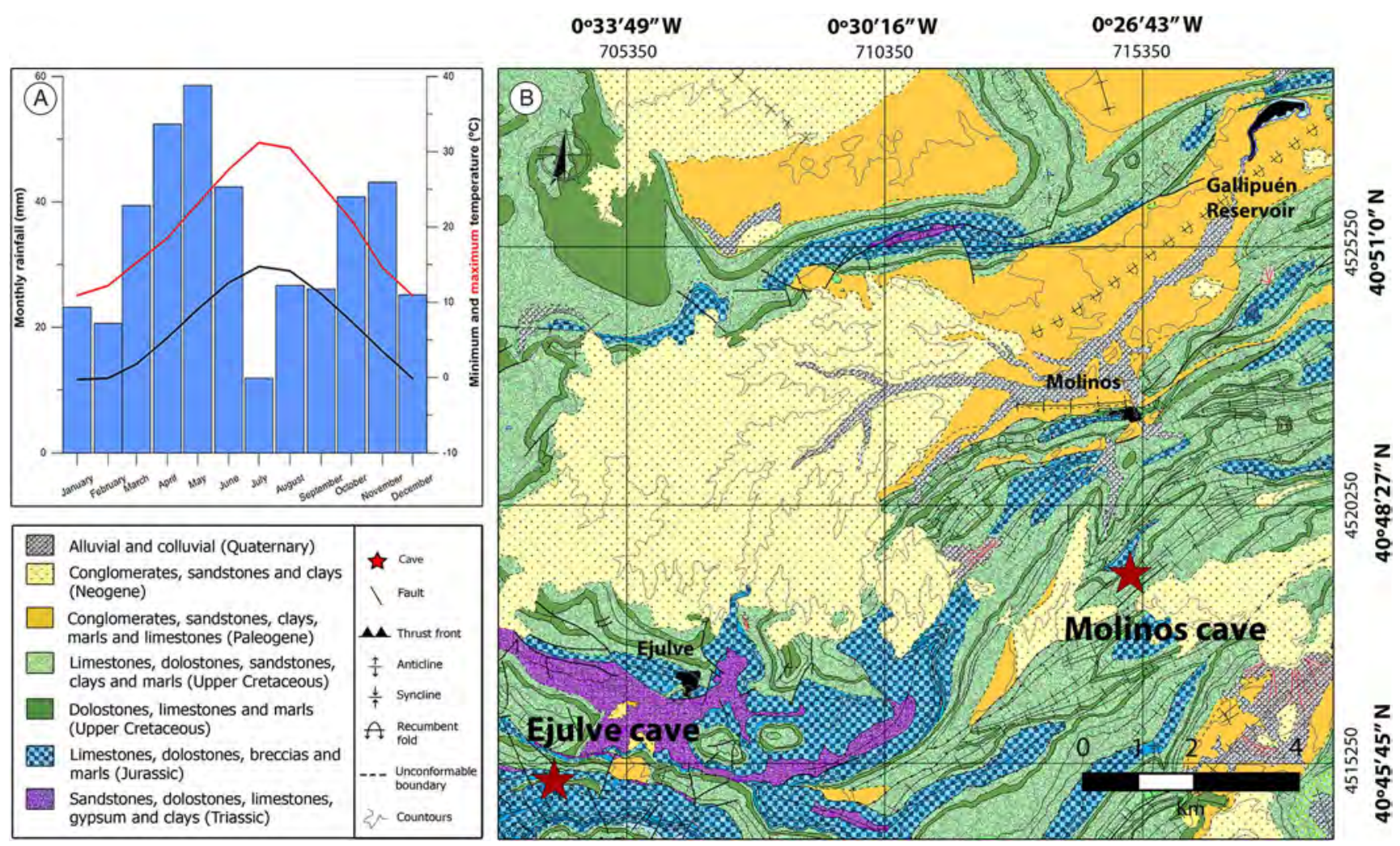

Figure 2. (color online) (A) Mean monthly rainfall $(\mathrm{mm})$ and maximum and minimum temperature $\left({ }^{\circ} \mathrm{C}\right)$ at the closest meteorological station (Gallipuén reservoir), averaged for the last five years. (B) Geological map where Molinos and Ejulve villages and both studied caves are indicated. Gallipuén reservoir is also shown. Legend with lithological formations is included.

(Ejulve, Teruel), hereafter Ejulve cave $\left(40^{\circ} 45^{\prime} 31^{\prime \prime} \mathrm{N} ; 0^{\circ} 35^{\prime} 8^{\prime \prime} \mathrm{W}\right.$; $1240 \mathrm{~m}$ asl), located $12 \mathrm{~km}$ west, developed in Upper Cretaceous (Cenomanian) dolomitic limestones and dolostones (Fig. 2B).

The regional landscape is dominated by high-altitude remnants of planation surfaces. The final stage of planation, during Pliocene times, is accompanied by intensive karst processes, leading to development of large fields of dolines and poljes. However, endokarstic systems are poorly developed. Molinos and Ejulve Caves are made of a maze of single rectilinear conduits guided by host rock fractures. In addition, individual rooms, narrow passages, cupolas, and cups are frequent. Molinos Cave is made of two sectors (upper and lower) with a total length of $620 \mathrm{~m}$ of galleries, including several rooms and halls. Ejulve Cave is developed along $794 \mathrm{~m}$ of galleries, reaching $55 \mathrm{~m}$ depth. After cave development, spectacular vadose speleothems decorates have been found in both caves, particularly in Molinos Cave.

The study area is characterized today by a continental Mediterranean climate, with high seasonal contrast between very hot summers (maximum mean temperature in August, the warmest month, is $32^{\circ} \mathrm{C}$ ) and very cold winters (minimum mean temperature in January, the coldest month, is $0^{\circ} \mathrm{C}$ ) and $500 \mathrm{~mm}$ of mean annual precipitation, occurring fall through spring, with a maxima in May (Fig. 2A). Thus, the rainiest season in this particular area in the northwestern Mediterranean Basin is divided into a primary maximum during the spring and a secondary in fall, making for a shorter dry season than in the classic Mediterranean climate (Peel et al., 2007). At present-day, the soil preserved is scarce and the limestone thickness above both caves is less than $20 \mathrm{~m}$, thus leading to a rapid hydrological response to rainfall (Moreno et al., 2014). As a consequence of the poor soil development, the high erosion rates, and centuries of intense human impact (mainly grazing activities), the vegetation cover appears degraded. The result is a patchy landscape dominated by diverse heliophytic shrubs (e.g., Quercus coccifera, Thymus vulgaris, Rosmarinus officinalis, Lavandula spp., Salvia spp., and Genista scorpius), holm oaks (Quercus ilex subsp. ballota), as well as the scarce presence of semi-deciduous oaks (Quercus faginea), the latter confined to humid gorges and shaded exposures. A local wildfire in the surroundings of Ejulve Cave in summer of 2009 reduced the vegetation cover.

\section{METHODOLOGY}

A monitoring survey was carried out in both caves including continuous logging of environmental variables and, on a monthly basis, dripwater and in-farmed carbonate sampling (two sites in Molinos Cave and nine sites in Ejulve Cave), later analyzed for stable isotopes and chemical composition to help with interpreting proxy data (see Supplementary material and Supplementary Fig. 1). Additionally, a previous study based on $2.5 \mathrm{yr}$ of rainfall monitoring was used to 
understand present-day controlling factors on the isotopic composition of precipitation events (Moreno et al., 2014).

Two stalagmites from Molinos cave (MO-1 and MO-7) and one from Ejulve cave (HOR) were collected in situ, cut parallel to the growth axis, and the central segment was sampled for U-Th dating, stable isotopes, and major and trace elements, except for high porosity sections where sampling was shifted to more well-defined layers to extract the most pristine isotope signal (Supplementary Fig. 2). Samples for isotopes $\left(\delta^{13} \mathrm{C}\right.$ and $\left.\delta^{18} \mathrm{O}\right)$ and $\mathrm{Mg} / \mathrm{Ca}$ were drilled along the central axis of the stalagmite using a $0.5-\mathrm{mm}$ drill bit $(1-\mathrm{mm}$ intervals in MO-7; 5-mm intervals in MO-1 and HOR).

Stable isotope analyses (speleothems and glass slides) were performed at the University of Barcelona (ScientificTechnical Services), Spain, using a Finnigan-MAT 252 mass spectrometer, fitted with a Kiel Carbonate Device I. Standards were run every 6 samples with a reproducibility better than $0.03 \%$ and $0.06 \%$ for $\delta^{13} \mathrm{C}$ and $\delta^{18} \mathrm{O}$, respectively. Sample duplicates, run every 10 to 20 samples to check for homogeneity, replicated within $0.1 \%$. Isotope values are reported $\%$ with respect to the Vienna Pee Dee Belemnite (VPDB) standard.

Elemental chemical composition was analyzed using matrix-matched standards on a simultaneous dual inductively coupled plasma-atomic emission spectrometer (Thermo ICAP DUO 6300 at the University of Oviedo for MO-1 and HOR and at the Pyrenean Institute of Ecology for MO-7) following the procedure described in Moreno et al. (2010). Reported ratios are from measurement of $\mathrm{Ca}(315.8 \mathrm{~nm})$ and $\mathrm{Mg}(279.5 \mathrm{~nm})$, all in radial mode.

Dates from U-Th decay were obtained at the University of Minnesota (20 samples for MO-1 and 23 samples for HOR) and at the University of Melbourne (7 samples for MO-7) using a multiple collector mass spectrometer with a plasma source (Thermo-Finnigan Neptune) and following the methodology described previously (Supplementary Table 1; Cheng et al., 2013; Hellstrom, 2006). Once again, sample portions characterized by high porosity and frequent voids were avoided to minimize the effect of open system behavior and consequent age inversions. During several intervals, two or three stalagmites grew contemporaneously, making it possible to test whether the proxy signals recorded in individual stalagmites are reproducible. We a priori assume that the $\delta^{18} \mathrm{O}$ records of the three stalagmites represent one common signal. Then, the records are combined with iscam (intra-site correlation age modeling; Fohlmeister, 2012), a method that correlates dated proxy signals from several stalagmites, determines the most probable age-depth model (Fig. 3), and calculates the age uncertainty for the combined record (see Supplementary Fig. 3-4). The lack of correlation among the $\delta^{18} \mathrm{O}$ and $\delta^{13} \mathrm{C}$ records in the three speleothems, together with the different factors influencing isotopic composition of rainfall in the area (Moreno et al., 2014), including the variation in the moisture source, makes the interpretation of Holocene $\delta^{18} \mathrm{O}$ records unrealistic in terms of only one climate variable. Thus, this proxy is used in the chronology

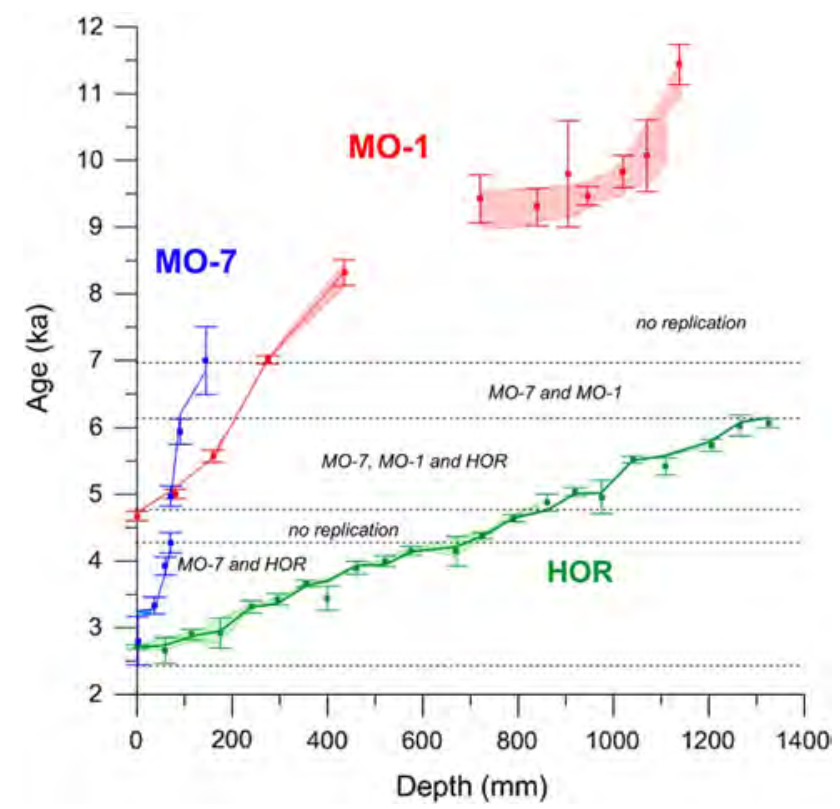

Figure 3. (color online) Th/U ages (solid squares) and associated 2-бigma uncertainties, as well as the age-depth models (solid line) for the three stalagmites calculated using Iscam (Fohlmeister, 2012). The shaded areas define the 2-бigma uncertainty range. The thin dotted lines denote periods that are contained in two or more stalagmites (i.e., overlapping sections).

construction by iscam but not to discuss paleoenvironmental implications.

\section{HYDROLOGICAL FLUCTUATIONS ACROSS MEDITERRANEAN IBERIA DURING THE HOLOCENE}

\section{Winter-spring signal in the Iberian range speleothems}

A previous study on the origin of rainfall based on the isotopic composition of rainfall events during three years in the Iberian range demonstrated that precipitation comes both from Atlantic and Mediterranean sources (Moreno et al., 2014). At the cave locations, leeward of the Atlantic influence, spring is the rainiest season (Fig. 2A), whereas winter is relatively dry and winter precipitation is not related to the North Atlantic Oscillation (NAO) pattern (Martin-Vide and Lopez-Bustins, 2006; Lopez-Bustins et al., 2008). On the contrary, a moderate negative correlation, statistically significant between $\delta^{18} \mathrm{O}$ rainfall values and western Mediterranean Oscillation index (WeMOi), is described previously for this area, with a Spearman's rank annual correlation coefficient of -0.25 and a $P$ value of 0.046 in spring (Moreno et al., 2014). The WeMOi has its greatest influence in the eastern fringe of the Iberian Peninsula, being especially well correlated to rainfall amount in winterspring. This correlation suggests that regional atmospheric teleconnections, linked to the western Mediterranean pressure system's patterns of variability, control the 
incidence of storms associated with northeastern cyclogenesis (Lopez-Bustins, J.-A., 2008). Importantly, this synoptic pattern ("back-door fronts" in Supplementary material, Supplementary Fig.1) is dominant during the end of the winter through the beginning of spring, indicating the influence of a Mediterranean origin in that part of the year when the amount of precipitation is higher (Fig. 2A). Coherently, calcite precipitates on glass slides occur during seasons of positive water balance, autumn through spring, suggesting a seasonal bias in the obtained speleothem records (see Supplementary Fig. 1). Thus, elevated deposition rates may bias the isotopic signature of stalagmites fed by seasonally responsive drips toward the rainy season values in both caves.

Absolute values of $\delta^{13} \mathrm{C}$ are slightly different in HOR, MO-1, and MO-7, varying between $-7.6 \%$ and $-10.12 \%$ in Ejulve cave and between $-6.06 \%$ and $-11.24 \%$ in Molinos cave (Fig. 4). This different amplitude in the range of variation may be explained by the host rock composition, considering that both caves are below similar rock thickness (less than $20 \mathrm{~m}$ ) and similar soil and vegetation cover development (today and very likely during the Holocene). Thus, Ejulve cave originated on Cenomanian dolostones, while the host rock of Molinos cave is formed by crystalline marine limestones of Cenomanien-Turonian age. As dolostones are less prone to dissolution than limestones, a lower range of variation should be expected in the $\delta^{13} \mathrm{C}$ profile from HOR sample compared to Molinos stalagmites, indicating less influence of the interaction with host rock in Ejulve cave. In addition, the HOR sample is characterized by higher growth rates than Molinos samples, pointing to faster dripwater flow and thus, less time for rock-water exchange. In coherence with these growth rate differences, $\mathrm{Mg} / \mathrm{Ca}$ values are lower and less variable in the HOR stalagmite from Ejulve cave than in the Molinos MO-1 sample (see different y-axis in Fig. 4). We hypothesize that the higher growth rates in HOR compared to Molinos samples point to faster carbonate precipitation and, consequently, less time for $\mathrm{Ca}^{2+}$ to precipitate.

In addition, the dominance of a columnar fabric (see Supplementary material) helps to interpret that these speleothems precipitated close to isotopic equilibrium (Belli et al., 2013). This assumption is corroborated by the large diameter of the stalagmite, which is considered typical for stalagmites that reflect the original composition of drip water (Dreybrodt and Scholz, 2011). Consequently, $\delta^{13} \mathrm{C}$ values should reflect processes external to the two studied caves, such as soil dissolved inorganic carbon (DIC). Thus, in spite of the different range of variation, $\delta^{13} \mathrm{C}$ profiles from the three stalagmites are similar in their general trends (Fig. 4, plotted at the same scale), this correlation suggesting a common mechanism controlling the $\delta^{13} \mathrm{C}$ records despite the notable differences in the host rock composition and the different features of the stalagmites (e.g., growth rates).

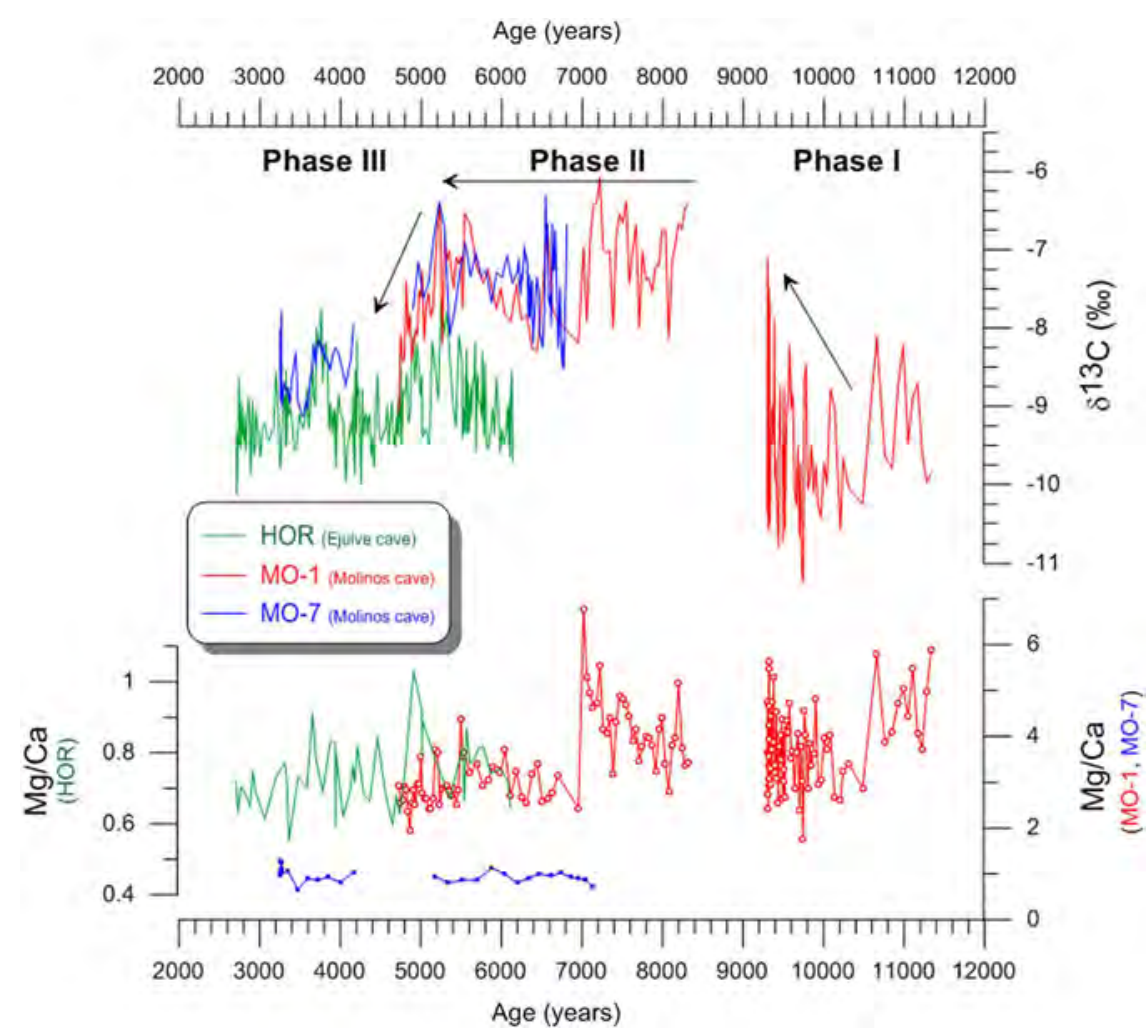

Figure 4. Carbon $\left(\delta^{13} \mathrm{C}\right)$ isotope values vs. time from HOR (green line), MO-7 (blue line), and MO-1 (red line), compared with $\mathrm{Mg} / \mathrm{Ca}$ from the same stalagmites. Three phases are indicated. (For interpretations of the references to color in this figure legend, the reader is referred to the web version of this article.) 
The trends in the $\delta^{13} \mathrm{C}$ variation over the whole Holocene can be described in terms of three intervals (Phases in Fig. 4). First, the lightest values (-12\%o to $-8 \%$ ) are observed in the early Holocene (11.7-9.4 ka) represented in MO-1. Second, a tendency towards higher values is observed after a hiatus (9.4-8.5 ka) and later maintained during the middle Holocene (-8\%o to $-6 \%$ ), recorded by MO-1, MO-7 and HOR speleothems from 8.5 to $4.8 \mathrm{ka}$. Finally, after $4.8 \mathrm{ka}$, lower values (-9\%o to $-10 \%$ ) are observed again. Although these three phases are not so evident in $\mathrm{Mg} / \mathrm{Ca}$ profiles from HOR and MO-1, still the correlation between $\mathrm{Mg} / \mathrm{Ca}$ and $\delta^{13} \mathrm{C}$ is high, with Spearman's correlation coefficients of 0.52 $(P$ value $<0.0001)$ for HOR and $0.28(P$ value $<0.0001)$ for MO-1. In contrast, the MO-7 sample, with lower resolution, displays a $\mathrm{Mg} / \mathrm{Ca}$ record not similar in trends or values to the other two speleothems (Fig. 4). Therefore, the $\mathrm{Mg} / \mathrm{Ca}$ profile from MO-7 is not used for further interpretations.

Interpretation of $\delta^{13} \mathrm{C}$ variation must consider that carbon in speleothem calcite has two main sources: (1) soil $\mathrm{CO}_{2}$, which is controlled by atmospheric $\mathrm{CO}_{2}$, plant respiration, and aged organic matter degradation; and (2) bedrock carbonate $\left(\mathrm{CaCO}_{3}\right)$ that is dissolved during seepage. In this way, in a dry period, soil activity and vegetation above the cave decrease and cause higher $\delta^{13} \mathrm{C}$ values of soil $\mathrm{CO}_{2}$ and, later on, enriched isotope values of speleothem carbonate (Genty et al., 2006; Moreno et al., 2010). In this cave setting, the influence of age of respired soil gas $\mathrm{CO}_{2}$ due to ancient organic matter degradation (important in tropical climates, Noronha et al., 2014) is considered negligible due to the dryness of this Mediterranean area, with expected low soil development and scarce organic matter. It is important to note that, for the studied time interval, there was no human transformation of the landscape in this region until the Iron Age (ca. 2800-2500 yr), when there was an expansion of human occupation and an increase in settlements (Ibáñez and Burillo, 1995). Possibly, as a consequence of this increase in population, soil degradation may have happened (Ibáñez and Burillo, 1995 and references therein). From that time on, only limited calcite precipitation was observed in both studied caves, suggesting a change in the cave hydrology.

Regarding the influence of vegetation cover in the $\delta^{13} \mathrm{C}$ records, we need to take into account that the hydrological balance in this region is negative, making moisture availability the more critical factor for forest development. In fact, recent studies have demonstrated that the variability in the amount of rain during spring season is the main cause for regional forest expansion or decline (Camarero et al., 2015).

An additional factor, proven to be of influence in $\delta^{13} \mathrm{C}$ records from other caves in northern Iberia (Moreno et al., 2010) and southern France (Genty et al., 2006), is the extent of $\mathrm{CO}_{2}$ degassing prior to calcite precipitation on top of the stalagmite. Higher degrees of degassing accompany the slower drip rates and percolation through unsaturated epikarst conduits during periods of lower rainfall and result in differential ${ }^{12} \mathrm{C}$ release and more positive $\delta^{13} \mathrm{C}$ values in precipitated calcite. However, in these speleothems, the lack of correlation among $\delta^{13} \mathrm{C}$ and $\delta^{18} \mathrm{O}$ and the dominant fabrics (compact columnar, see Supplementary material) indicate precipitation close to equilibrium (Frisia et al., 2000). Therefore, in this case, $\delta^{13} \mathrm{C}$ is reflecting the soil-carbon pool, which is mostly derived from the extent of soil microbial respiration (Fairchild and Baker, 2012), which in this regional climate is limited by the amount and timing of soil moisture. Under these premises, the $\delta^{13} \mathrm{C}$ values depend on the combination of soil- and limestone-derived carbon, from which the DIC in groundwater derives (e.g., Rudzka et al., 2011).

Thus, interpreting the $\delta^{13} \mathrm{C}$ profiles in these terms, the three-part Holocene can be described in terms of water availability during the rainy season (Fig. 4), with a wetter period from the Holocene onset to ca. 9.4 ka (Phase I, characterized by lower $\delta^{13} \mathrm{C}$ values); drier from 8.5 to $4.8 \mathrm{ka}$ (Phase II, with higher $\delta^{13} \mathrm{C}$ values); and wet again afterwards (Phase III, with generally lower $\delta^{13} \mathrm{C}$ values again). The hiatus from 9.4 to $8.5 \mathrm{ka}$ may be associated to the onset of Phase II (dry) but the lack of records prevents a strong interpretation here. Differences between Phase II and Phase III are not so visually evident in HOR sample, but the average values differ by $1.3 \%$, with lower $\delta^{13} \mathrm{C}$ values in Phase III.

Despite some of the potential complexities of using speleothem $\mathrm{Mg}$ as a paleohydrological proxy, many studies have demonstrated a convincing relationship between dripwater and/or speleothem $\mathrm{Mg}$ and recorded rainfall (e.g., McMillan et al., 2005; Fairchild and Treble, 2009). Significant correlation observed in MO-1 and HOR speleothems among $\delta^{13} \mathrm{C}$ and $\mathrm{Mg} / \mathrm{Ca}$ suggests either that periods of reduced soil microbial activity (heavier soil $\mathrm{CO}_{2} \delta^{13} \mathrm{C}$ ) were also drier (high $\mathrm{Mg} / \mathrm{Ca}$ ), and/or that a small portion of the $\delta^{13} \mathrm{C}$ variation arises from degassing and prior calcite precipitation effects caused by humidity variations (Moreno et al., 2010). Although the second case is less acceptable here as explained above, in both cases, dry periods would most plausibly lead to higher $\delta^{13} \mathrm{C}$ and $\mathrm{Mg} / \mathrm{Ca}$ ratios. Beyond the observed correlation, the abruptness of the $\mathrm{Mg} / \mathrm{Ca}$ variation is markedly different from that of the isotopes, suggesting different thresholds of sensitivity (e.g., growth rate, different host rock).

\section{Seasonality as the key for reconciling records on hydrological variability during the Holocene}

The three stages defined in terms of hydrological variability appear synchronous with the signal observed in lake level records north of ca. $40^{\circ} \mathrm{N}$ in the central Mediterranean (see location in Fig. 1: Accesa, Cerin, and Ledro lakes; e.g., Magny et al., 2013), that is, two humid periods (before ca. $9 \mathrm{ka}$ and after $4.5 \mathrm{ka}$ ) separated by a drier phase (see Accesa lake level in Fig. 5c). Interestingly, in spite of the different timing of transitions, the same three-part pattern is reproduced in Bunker cave stalagmites (Germany; see location in Fig. 1), where a winter signal is demonstrated as the result of enhanced evapotranspiration during summer months leading to reduced infiltration into the karst aquifer (Fig. 5d; Fohlmeister et al., 2012). One could argue that this three-part pattern represents the more Mediterranean characteristics recorded in our studied caves compared to other Iberian 


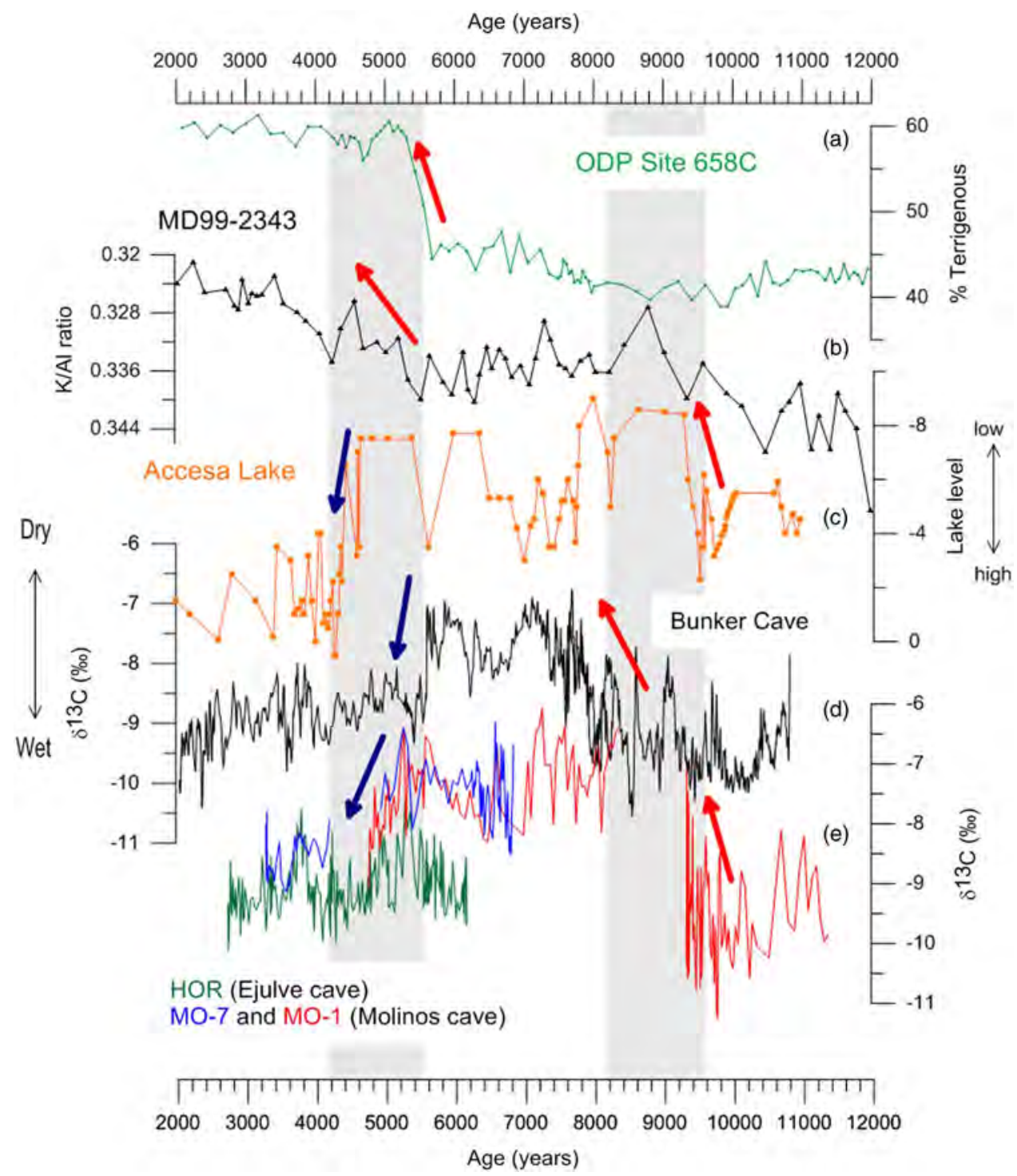

Figure 5. Comparison of Holocene paleo humidity records. (A) Percentage of terrigenous (aeolian flux) from ODP Site 658 (northwest African margin) indicating (arrow) the end of the African Humid Period (deMenocal et al., 2000). (B) K/Al ratio from MD99-2343 (Minorca island, northwest Mediterranean) marking the decrease in fluvial input throughout the Holocene (two steps indicated by arrows; Frigola et al., 2007). (C) Lake level oscillations in Accesa Lake (North Italy; Magny et al., 2003). (D) Bunker cave (W Germany; Fohlmeister et al., 2012). (E) $\delta^{13} \mathrm{C}$ values from HOR (green line), MO-7 (blue line), and MO-1 (red line). Note that the axis-y orientation is inverted to mark drier conditions towards the top of the page. Gray bars indicate the two transitional periods: first, from the early to middle Holocene and, second, from the middle to late Holocene. (For interpretations of the references to color in this figure legend, the reader is referred to the web version of this article.)

records regulated by Atlantic conditions, such as Pyrenean lake records (González-Sampériz et al., 2006; Gil-Romera et al., 2014), northwest Iberian lakes (Santos et al., 2000; López-Merino et al., 2012), or speleothem records from northern Iberian coast (e.g., Stoll et al., 2013; see location of all cited records in Fig. 1). Thus, the comparison among speleothem $\delta^{13} \mathrm{C}$ profiles and other records of water availability is attempted (Fig. 5).

Regarding the hydrological signal recorded from sequences under typical Mediterranean climate, fluvial supply to marine sediments from offshore Minorca island (marine core MD99-2343; Frigola et al., 2007) are compared to our speleothem records (Fig. 5). The $\mathrm{K} / \mathrm{Al}$ ratio is considered a good indicator for clay inputs (mainly illite) from river runoff. Thus, its variation (Fig. 5b) is interpreted to indicate higher humidity during the early Holocene that gradually decreases in concert with the end of the African Humid Period, that is, associated with the decrease in orbitally-driven summer insolation and thus marked by an increase in aeoliantransported particles (Fig. 5a; Harrison and Digerfeldt, 1993; deMenocal et al., 2000). The decrease in humidity in Minorca core is in two phases, one ca. $9.5 \mathrm{ka}$ and the second one, more intense, at ca. $5 \mathrm{ka}$ (arrows in Fig. 5b). A recent study on one stalagmite from southern Iberia $\left(36^{\circ} \mathrm{N}\right)$ based on calcite 
density variations was interpreted to reflect a decrease of humidity after $5.3 \mathrm{ka}$ (Walczak et al., 2015) once the speleothem becomes more porous. Other records under Mediterranean climate are similar to this pattern (e.g., El Maillo record from Iberian Central Range; Morales-Molino et al., 2013), although the early Holocene is not always a period with high water availability but, in contrast, characterized by long dry summers that would be probably determinant in the hydric balance recorded by lake sediments.

Other examples of the Iberian "typical Mediterranean" pattern (dry-wet-dry) are Villarquemado paleolake (Aranbarri et al., 2014) and Ojos del Tremedal sequences (Stevenson, 2000) both located in the Iberian Range, or Estanya lake in the Pre-Pyrenees (Morellón et al., 2008), where the early Holocene is still cold and relatively dry and the most humid interval covers from 9 to $5 \mathrm{ka}$, generally related to the "Holocene Climate Optimum" concept in terms of forest expansion (González-Sampériz et al., 2017). In the same way, Sancho et al., (2015) identified a maximum of tufa deposition at $7 \mathrm{ka}$ in northeastern Iberia under wet conditions. This pattern is also coherent with other records located at higher altitude but still under Mediterranean influence, for example Basa de la Mora lake record (Pérez-Sanz et al., 2013) in the Pyrenees, Siles lake in the Segura mountains of southern Spain (Carrión, 2002), or Borreguiles de la Virgen in the Sierra Nevada (Fig. 1; García-Alix et al., 2012).

Comparing Molinos and Ejulve records with sequences under the direct influence of Atlantic climate is the second step. In general, Holocene climate reconstructions from sites located in northern Iberia indicate the control of orbitallydriven insolation, with an inflection at ca. 6-5 ka (e.g., Muñoz Sobrino et al., 2005). Most pollen-based climate reconstructions from Atlantic Iberia show an early Holocene rapid transition to vegetation dominated by temperate deciduous woodland, a maximum forest development up to about $8 \mathrm{ka}$, and a transition during the late Holocene to the current disturbance-adapted vegetation (see a review in Carrión et al., 2010). Similarly, the compilation of growth rates from up to 15 stalagmites in northern Spain indicates a change from wet early Holocene to drier conditions after $6 \mathrm{ka}$ and the cessation of most growth by $4.1 \mathrm{ka}$ (Stoll et al., 2013).

Clearly, the opposite pattern (wet-dry-wet) found in our Iberian Range speleothems compared to most Mediterranean sequences (dry-wet-dry) indicates that interpretation of the $\delta^{13} \mathrm{C}$ record as changes in Mediterranean-related humidity requires an additional explanation (e.g., different season of humidity). Additionally, the lack of correlation with most Atlantic sequences leads us to confirm that our $\delta^{13} \mathrm{C}$ profiles are not directly representing the humidity variability derived from the entrance of westerly-driven Atlantic fronts. We propose that Molinos and Ejulve records are shaped mainly by Mediterranean-sourced precipitation but during the end-of-winter/beginning-of-spring, a season not generally represented by other sequences.

Additionally, information about fire frequency reconstructed from charcoal records in western Mediterranean lacustrine sites reflects a different variation in records from northern and southern Mediterranean Iberia. Thus, higher values of fire frequency were observed during the "Holocene Climate Optimum" around 8-5 ka in records from northeastern Iberia (Las Pardillas, El Carrizal, Ojos del Tremedal, and Hoya del Castillo) while records from the southern Mediterranean Iberia (including Siles Lake, Cañada de la Cruz, Villaverde, and Navarrés) indicate a decrease associated with wetter-than-present summers (Vanniere et al., 2011). This pattern is very similar to our record in northeastern Iberia with the drier period during 8-5 ka. Particularly coherent is the fact that, after $5 \mathrm{ka}$, records from northern Mediterranean Iberia indicate an absence of fire activity, whereas a significant increase in fire activity was recorded in the south. This coherence likely highlights that Mediterranean precipitation in winter-spring season has been neglected in previous studies of hydrological variability along the Holocene.

Variations in both the synoptic-scale climate patterns and large-scale atmospheric circulation indexes (e.g., NAO and WeMOi) are invoked to explain the observed variability and, particularly, the lack of correlation among north and south Mediterranean records already proposed by Magny et al. (2013). In Molinos cave, precipitation of carbonate in artificial supports occurs from late fall to early spring (Moreno et al., 2014), the season with higher present-day correlation between amount of rainfall and WeMOi in this area (October to March in Martin-Vide and Lopez-Bustins, 2006). This index explains the pluviometric variability in the eastern fringe of the Iberian Peninsula, particularly in the Gulf of Valencia, since it allows the detection of the variability relevant to the cyclogenesis next to the western Mediterranean (Martin-Vide and Lopez-Bustins, 2006). Negative values of the WeMOi are correlated to higher precipitation in relation to the entrance of northeasterly flows over eastern Iberia (Lopez-Bustins et al., 2008). Therefore, at present-day, years with negative value of the WeMOi result in wetter winterspring seasons in the Iberian Range (leeward of the Atlantic influence) and, coherently, would produce more negative $\delta^{13} \mathrm{C}$ values in the precipitated calcite (e.g., early Holocene). This mechanism is possibly not true for southern Mediterranean Iberian records (e.g., El Refugio cave; Walczak et al., 2015), where winters are wet but related to the southern position of the North Atlantic Subtropical High and the associated westerlies; this area is under the influence of the NAO mechanism today (Trigo et al., 2004) and also for the late Holocene (Ramos-Román et al., 2016). Therefore, the operation of a mechanism similar to the present-day WeMOi with different intensity during the Holocene is considered the main force shaping Molinos and Ejulve speleothem records.

\section{CONCLUSIONS}

The three stalagmites presented here document significant climate changes in the Iberian Range mountains, northeastern Iberia, during the Holocene. From the combination of carbon 
isotope variations and $\mathrm{Mg} / \mathrm{Ca}$ ratio, the hydrological balance during the Holocene is reconstructed as a signal of winterspring Mediterranean-sourced precipitation, associated with the WeMOi pattern, and probably not related to westerly influences driven with NAO dynamics. Thus, we observed three phases in the water availability: (1) the early Holocene (11.7-9.4 ka), with lower $\delta^{13} \mathrm{C}$ values, low $\mathrm{Mg} / \mathrm{Ca}$, and high growth rates, appears as the wettest interval; (2) the middle Holocene (8.5-4.8 ka), characterized by a marked change towards aridity; and, (3) the late Holocene, with an increase of humidity afterwards (4.8-2 ka). This three-part pattern is in striking coherence with lake levels and fire frequency from northwestern and central Mediterranean sites (e.g., Accesa lake) and opposite that of southern Mediterranean sites. Differences may be explained by the spatial patterns of influence of the Mediterranean- and Atlantic-sourced precipitation associated at present with the WeMOi and NAO climate modes, respectively. Therefore, the past expression of those climate mechanisms allowed describing a simplified picture of hydrological changes across Iberia, integrating these new records in the previous knowledge of Holocene variability.

\section{ACKNOWLEDGMENTS}

The funding for this study derives from GA-LC-030/2011, GA-LC-021/ 2008, CGL2010-16376, CGL2009-10455/BTE, CTM2013-48639-C2$1-\mathrm{R}$, and CGL2016-77479-R projects. This is a contribution by Geomorfología y Cambio Clobal and PaleoQ groups (Aragón Government). We are indebted to Emilio and Javier from the Molinos council and Joaquín Perona (UB) for the analyses on calcite samples. César Azorín and Paleo-IPE group members are acknowledge for fruitful discussions. We are also grateful to J. Fohlmeister, one anonymous reviewer, and the associated editor M. Lachniet for their helpful comments that greatly improved the manuscript.

\section{Supplementary material}

To view supplementary material for this article, please visit https://doi.org/10.1017/qua.2017.39

\section{REFERENCES}

Aranbarri, J., González-Sampériz, P., Valero-Garcés, B., Moreno, A., Gil-Romera, G., Sevilla-Callejo, M., García-Prieto, E., et al. 2014. Rapid climatic changes and resilient vegetation during the Lateglacial and Holocene in a continental region of south-western Europe. Global and Planetary Change 114, 50-65.

Belli, R., Frisia, S., Borsato, A., Drysdale, R., Hellstrom, J., Zhao, J. X., Spötl, C., 2013. Regional climate variability and ecosystem responses to the last deglaciation in the northern hemisphere from stable isotope data and calcite fabrics in two northern Adriatic stalagmites. Quaternary Science Reviews 72, 146-158.

Camarero, J.J., Gazol, A., Tardif, J.C., Conciatori, F., 2015. Attributing forest responses to global-change drivers: limited evidence of a $\mathrm{CO}_{2}$ fertilization effect in Iberian pine growth. Journal of Biogeography 42, 2220-2233.
Carrión, J.S., 2002. Patterns and processes of Late Quaternary environmental change in a montane region of southwestern Europe. Quaternary Science Reviews 21, 2047-2066.

Carrión, J.S., Andrade, A., Bennett, K.D., Navarro, C., Munuera, M., 2001a. Crossing forest thresholds: inertia and collapse in a Holocene sequence from south-central Spain. The Holocene 11, 635-653.

Carrión, J.S., Fernández, S., González-Sampériz, P., Gil-Romera, G., Badal, E., Carrión-Marco, Y., López-Merino, L., López-Sáez, J.A., Fierro, E., Burjachs, F., 2010. Expected trends and surprises in the Lateglacial and Holocene vegetation history of the Iberian Peninsula and Balearic Islands. Review of Palaeobotany and Palynology 162, 458-475.

Carrión, J.S., Munuera, M., Dupré, M., Andrade, A., 2001 b. Abrupt vegetation changes in the Segura Mountains of southern Spain throughout the Holocene. Journal of Ecology 89, 783-797.

Carrión, J.S., van Geel, B., 1999. Fine-resolution Upper Weichselian and Holocene palynological record from Navarrés (Valencia, Spain) and a discussion about factors of Mediterranean forest succession. Review of Palaeobotany and Palynology 106, 209-236.

Cheng, H., Edwards, R.L., Shen, C-C., Woodhead, J., Hellstrom, J., Wang, Y.J., Kong, X.G., Spötl, C., Wang, X.F., Alexander, Jr, E.C., 2013. Improvements in 230Th dating, 230Th and 234U half-life values, and U-Th isotopic measurements by multi-collector inductively coupled plasma mass spectrometry. Earth and Planetary Science Letters 371, 82-91.

Constantin, S., Bojar, A.-V., Lauritzen, S.-E., Lundberg, J., 2007. Holocene and Late Pleistocene climate in the sub-Mediterranean continental environment: A speleothem record from Poleva Cave (Southern Carpathians, Romania). Palaeogeography, Palaeoclimatology, Palaeoecology 243, 322-338.

Davis, B.A.S., Stevenson, A.C., 2008. The $8.2 \mathrm{ka}$ event and Early-Mid Holocene forests, fires and flooding in the Central Ebro Desert, NE Spain. Quaternary Science Reviews 26, 1695-1712.

de Menocal, P., Ortiz, J., Guilderson, T.P., Adkins, J.F., Sarnthein, M., Baker, L., Yarunsiky, M., 2000. Abrupt onset and termination of the African Humid Period: rapid climate responses to gradual insolation forcing. Quaternary Science Reviews 19, 347-361.

Domínguez-Villar, D., Fairchild, I.J., Baker, A., Wang, X., Edwards, L.R., Cheng, H., 2009. Oxygen isotope precipitation anomaly in the North Atlantic region during the 8.2 ka event. Geology 37, 1095-1098.

Domínguez-Villar, D., Wang, X., Cheng, H., Martín-Chivelet, J., Edwards, R.L., 2008. A high-resolution late Holocene speleothem record from Kaite Cave, northern Spain: d18O variability and possible causes. Quaternary International 187, 40-51.

Domínguez-Villar, D., Wang, X., Krklec, K., Cheng, H., Edwards, R.L., 2017. The control of the tropical North Atlantic on Holocene millennial climate oscillations. Geology 45, 303-306. doi: 10.1130/ G38573.1

Dreybrodt, W., Scholz, D., 2011. Climatic dependence of stable carbon and oxygen isotope signals recorded in speleothems: From soil water to speleothem calcite. Geochimica et Cosmochimica Acta 75, 734-752.

Fairchild, I.J., Baker, A., 2012. Speleothem Science: From Process to Past Environments. John Wiley-Blackwell, Oxford.

Fairchild, I.J., Treble, P.C., 2009. Trace elements in speleothems as recorders of environmental change. Quaternary Science Reviews 28, 449-468.

Fletcher, W.J., Debret, M., Goñi, M.F.S., 2013. Mid-Holocene emergence of a low-frequency millennial oscillation in western 
Mediterranean climate: Implications for past dynamics of the North Atlantic atmospheric westerlies. The Holocene 23, 153-166.

Fohlmeister, J., 2012. A statistical approach to construct composite climate records of dated archives. Quaternary Geochronology 14, 48-56.

Fohlmeister, J., Schröder-Ritzrau, A., Scholz, D., Spötl, C., Riechelmann, D.F.C., Mudelsee, M., Wackerbarth, A., Gerdes, A., Riechelmann, S., Immenhauser, A., Richter, D.K., Mangini, A., 2012. Bunker Cave stalagmites: an archive for central European Holocene climate variability. Climate of the Past 8, 1751-1764.

Franco-Múgica, F., García-Antón, M., Maldonado-Ruíz, J., Morla-Juaristi, C., Sainz-Ollero, H., 2005. Ancient pine forest on inland dunes in the Spanish northern meseta. Quaternary Research 63, 1-14.

Frigola, J., Moreno, A., Cacho, I., Canals, M., Sierro, F.J., Flores, J.A., Grimalt, J.O., Hodell, D.A., Curtis, J.H., 2007. Holocene climate variability in the western Mediterranean region from a deepwater sediment record. Paleoceanography 22, doi:10.1029/2006PA001307.

Frisia, S., Borsato, A., Fairchild, I.J., McDermott, F., 2000. Calcite fabrics, growth mechanisms, and environments of formation in speleothems from the Italian Alps and southwestern Ireland. Journal of Sedimentary Research 70, 1183-1196.

García-Alix, A., Jiménez-Moreno, G., Anderson, R., Jiménez Espejo, F., Delgado Huertas, A., 2012. Holocene environmental change in southern Spain deduced from the isotopic record of a high-elevation wetland in Sierra Nevada. Journal of Paleolimnology 48, 471-484.

Genty, D., Blamart, D., Ghaleb, B., Plagnes, V., Causse, C., Bakalowicz, M., Zouari, K., et al. 2006. Timing and dynamics of the last deglaciation from European and North African delta C-13 stalagmite profiles - comparison with Chinese and South Hemisphere stalagmites. Quaternary Science Reviews 25, 2118-2142.

Gil-Romera, G., González-Sampériz, P., Lasheras-Álvarez, L., Sevilla-Callejo, M., Moreno, A., Valero-Garcés, B., López-Merino, L., et al. 2014. Biomass-modulated fire dynamics during the last glacial-interglacial transition at the Central Pyrenees (Spain). Palaeogeography, Palaeoclimatology, Palaeoecology 402. http://dx.doi.org/10.1016/j.palaeo.2014.03.015.

González-Sampériz, P., Aranbarri, J., Pérez-Sanz, A., Gil-Romera, G., Moreno, A., Leunda, M., Sevilla-Callejo, M., et al. 2017. Environmental and climate change in the southern Central Pyrenees since the Last Glacial Maximum: A view from the lake records. CATENA 149, 668-688.

González-Sampériz, P., Valero-Garcés, B.L., Moreno, A., Jalut, G., García-Ruiz, J.M., Martí-Bono, C., Delgado-Huertas, A., Navas, A., Otto, T., Dedoubat, J.J., 2006. Climate variability in the Spanish Pyrenees during the last 30,000 yr revealed by the El Portalet sequence. Quaternary Research 66, 38-52.

Harrison, S.P., Digerfeldt, G., 1993. European lakes as palaeohydrological and palaeoclimatic indicators. Quaternary Science Reviews 12, 233-248.

Hellstrom, J., 2006. U-Th dating of speleothems with high initial 230Th using stratigraphical constraint. Quaternary Geochronology 1, 289-295.

Ibáñez, E.J., Burillo, F., 1995. Arqueología: una aproximación al pasado de Molinos. Seminario de Arqueología y Etnología Turolense, Teruel, Spain.

Jalut, G., Amat, A.E., Bonnet, L., Gauquelin, T., Fontugne, M., 2000. Holocene climatic changes in the Western Mediterranean, from south-east France to south-east Spain. Palaeogeography, Palaeoclimatology, Palaeoecology 160, 255-290.
Lopez-Bustins, J.-A., Martin-Vide, J., Sanchez-Lorenzo, A., 2008. Iberia winter rainfall trends based upon changes in teleconnection and circulation patterns. Global and Planetary Change 63, 171-176.

López-Merino, L., Silva Sánchez, N., Kaal, J., López-Sáez, J.A., Martínez Cortizas, A., 2012. Post-disturbance vegetation dynamics during the Late Pleistocene and the Holocene: An example from NW Iberia. Global and Planetary Change 92-93, 58-70.

Magny, M., Bégeot, C., Guiot, J., Peyron, O., 2003. Contrasting patterns of hydrological changes in Europe in response to Holocene climate cooling phases. Quaternary Science Reviews 22, 1589-1596.

Magny, M., Combourieu Nebout, N., de Beaulieu, J.L., BoutRoumazeilles, V., Colombaroli, D., Desprat, S., Francke, A., et al. 2013. North-south palaeohydrological contrasts in the central Mediterranean during the Holocene: tentative synthesis and working hypotheses. Climate of the Past Discussions 9, 1901-1967.

Martín-Chivelet, J., Muñoz-García, M.B., Edwards, R.L., Turrero, M.J., Ortega, A.I., 2011. Land surface temperature changes in Northern Iberia since $4000 \mathrm{yr} \mathrm{BP}$, based on $\delta 13 \mathrm{C}$ of speleothems. Global and Planetary Change 77, 1-12.

Martin-Vide, J., Lopez-Bustins, J.-A., 2006. The Western Mediterranean Oscillation and rainfall in the Iberian Peninsula. International Journal of Climatology 26, 1455-1475.

McMillan, E.A., Fairchild, I.J., Frisia, S., Borsato, A., McDermott, F., 2005. Annual trace element cycles in calcite-aragonite speleothems: evidence of drought in the western Mediterrranean 1200-1100 yr BP. Journal of Quaternary Science 20, 423-433.

Morales-Molino, C., García-Antón, M., Postigo-Mijarra, J.M., Morla, C., 2013. Holocene vegetation, fire and climate interactions on the westernmost fringe of the Mediterranean Basin. Quaternary Science Reviews 59, 5-17.

Morellón, M., Valero-Garcés, B., Moreno, A., González-Sampériz, P., Mata, P., Romero, O., Maestro, M., Navas, A., 2008. Holocene palaeohydrology and climate variability in northeastern Spain: The sedimentary record of Lake Estanya (Pre-Pyrenean range). Quaternary International 181, 15-31.

Morellón, M., Valero-Garcés, B., Vegas-Vilarrúbia, T., GonzálezSampériz, P., Romero, Ó., Delgado-Huertas, A., Mata, P., Moreno, A., Rico, M., Corella, J.P., 2009. Lateglacial and Holocene palaeohydrology in the western Mediterranean region: The Lake Estanya record (NE Spain). Quaternary Science Reviews 28, 2582-2599.

Moreno, A., Sancho, C., Bartolomé, M., Oliva-Urcia, B., DelgadoHuertas, A., Estrela, M.J., Corell, D., López-Moreno, J.I., Cacho, I., 2014. Climate controls on rainfall isotopes and their effects on cave drip water and speleothem growth: the case of Molinos cave (Teruel, NE Spain). Climate Dynamics 43, 221-241.

Moreno, A., Stoll, H.M., Jiménez-Sánchez, M., Cacho, I., Valero-Garcés, B., Ito, E., Edwards, L.R., 2010. A speleothem record of rapid climatic shifts during last glacial period from Northern Iberian Peninsula. Global and Planetary Change 71, 218-231.

Muñoz Sobrino, C., Ramil-Rego, P., GóMez-Orellana, L., Díaz Varela, R., 2005. Palynological data on major Holocene climatic events in NW Iberia. Boreas 34, 381-400.

Noronha, A.L., Johnson, K.R., Hu, C., Ruan, J., Southon, J.R., Ferguson, J.E., 2014. Assessing influences on speleothem dead carbon variability over the Holocene: Implications for speleothem-based radiocarbon calibration. Earth and Planetary Science Letters 394, 20-29. 
Peel, M.C., Finlayson, B.L., McMahon, T.A., 2007. Updated world map of the Köppen-Geiger climate classification. Hydrology and Earth System Science 11, 1633-1644.

Pérez-Sanz, A., González-Sampériz, P., Moreno, A., Valero-Garcés, B., Gil-Romera, G., Rieradevall, M., Tarrats, P., et al. 2013. Holocene climate variability, vegetation dynamics and fire regime in the central Pyrenees: the Basa de la Mora sequence (NE Spain). Quaternary Science Reviews 73, 149-169.

Railsback, L.B., Liang, F., Vidal Romaní, J.R., Grandal-d'Anglade, A., Vaqueiro Rodríguez, M., Santos Fidalgo, L., Fernández Mosquera, D., Cheng, H., Edwards, R.L., 2011. Petrographic and isotopic evidence for Holocene long-term climate change and shorter-term environmental shifts from a stalagmite from the Serra do Courel of northwestern Spain, and implications for climatic history across Europe and the Mediterranean. Palaeogeography, Palaeoclimatology, Palaeoecology 305, 172-184.

Ramos-Román, M.J., Jiménez-Moreno, G., Anderson, R.S., GarcíaAlix, A., Toney, J.L., Jiménez-Espejo, F.J., Carrión, J.S., 2016. Centennial-scale vegetation and North Atlantic Oscillation changes during the Late Holocene in the southern Iberia. Quaternary Science Reviews 143, 84-95.

Roberts, N., Brayshaw, D., Kuzucuoglu, C., Perez, R., Sadori, L., 2011. The mid-Holocene climatic transition in the Mediterranean: Causes and consequences. The Holocene 21, 3-13.

Rudzka, D., McDermott, F., Baldini, L.M., Fleitmann, D., Moreno, A., Stoll, H., 2011. The coupled [delta]13C-radiocarbon systematics of three Late Glacial/early Holocene speleothems; insights into soil and cave processes at climatic transitions. Geochimica et Cosmochimica Acta 75, 4321-4339.

Sánchez-Goñi, M.F.S., Hannon, G.E., 1999. High-altitude vegetational pattern on the Iberian Mountain Chain (north-central Spain) during the Holocene. The Holocene 9, 39-57.

Sancho, C., Arenas, C., Vázquez-Urbez, M., Pardo, G., Lozano, M.V., Peña-Monné, J.L., Hellstrom, J., et al. 2015. Climatic implications of the Quaternary fluvial tufa record in the
NE Iberian Peninsula over the last 500 ka. Quaternary Research 84, 398-414.

Santos, L., Vidal Romani, J.R., Jalut, G., 2000. History of vegetation during the Holocene in the Courel and Queixa Sierras, Galicia, northwest Iberian Peninsula. Journal of Quaternary Science 15, 621-632.

Smith, A.C., Wynn, P.M., Barker, P.A., Leng, M.J., Noble, S.R., Tych, W., 2016. North Atlantic forcing of moisture delivery to Europe throughout the Holocene. Scientific Reports 6, 24745. http://dx.doi.org/10.1038/srep24745.

Stevenson, A.C., 2000. The Holocene forest history of the Montes Universales, Teruel, Spain. The Holocene 10, 603-610.

Stoll, H.M., Moreno, A., Mendez-Vicente, A., Gonzalez-Lemos, S., Jimenez-Sanchez, M., Dominguez-Cuesta, M.J., Edwards, R.L., Cheng, H., Wang, X., 2013. Paleoclimate and growth rates of speleothems in the northwestern Iberian Peninsula over the last two glacial cycles. Quaternary Research 80, 284-290.

Trigo, R.M., Pozo-Vázquez, D., Osborn, T.J., Castro-Díez, Y., Gámiz-Fortis, S., Esteban-Parra, M.J., 2004. North Atlantic oscillation influence on precipitation, river flow and water resources in the Iberian Peninsula. International Journal of Climatology 24, 925-944.

Vanniere, B., Power, M.J., Roberts, N., Tinner, W., Carrion, J., Magny, M., Bartlein, P., et al. 2011. Circum-Mediterranean fire activity and climate changes during the mid-Holocene environmental transition (8500-2500 cal. BP). The Holocene 21, 53-73.

Wackerbarth, A., Scholz, D., Fohlmeister, J., Mangini, A., 2010. Modelling the $\delta 180$ value of cave drip water and speleothem calcite. Earth and Planetary Science Letters 299, 387-397.

Walczak, I.W., Baldini, J.U.L., Baldini, L.M., McDermott, F., Marsden, S., Standish, C.D., Richards, D.A., Andreo, B., Slater, J., 2015. Reconstructing high-resolution climate using CT scanning of unsectioned stalagmites: A case study identifying the mid-Holocene onset of the Mediterranean climate in southern Iberia. Quaternary Science Reviews 127, 117-128. 